\title{
Extravagant Rituals or Ethical Religion (Micah 6:6- 8)? Ritual Interface with Social Responsibility in Micah $^{1}$
}

\author{
Blessing O. Boloje (University OF Pretoria)
}

\begin{abstract}
The phenomenon of ritual criticism in prophetic writings of the $\mathrm{HB} / O T$ is one that highlights the discrepancy between ritual and lifestyle on the one hand and emphasizes the significance of rituals for the improvement of ethical life of people. Rituals are viewed as Ancient Israelite's vertical dimension of the relationship between God and man while ethics are its horizontal components (man to man relationship). In Micah, rituals are presented as acts of people's relationship with Yahweh (worship, offering and sacrifices) that do not impact positively on the horizontal dimension (social justice). This dysfunction of relationship is poignantly addressed by Micah as his oracle switches from confrontation to reconciliation. This article addresses the confrontation between Yahweh and Israel/Judah by juxtaposing two dominant spheres of Israel/Judah's religious life; ritual and lifestyle. Micah 6:6-8 stands in sharp contrast to the extravagance and mockery of rituals and as an alternative presents a message most profound and insightful for an invaluable decision. A truly ethical religion, Micah holds, is not about extravagant rituals but personal duty and responsibility for fulfilling that duty in society.
\end{abstract}

KEYWORDS: ethical religion, extravagant rituals, Micah, social responsibility, vertical and horizontal relationship, law and ethics

\section{A INTRODUCTION}

The phenomenon of prophetic indictment of rituals ${ }^{2}$ in the Hebrew Bible/Old Testament (HB/OT) is one that highlights the discrepancy between ritual and lifestyle on the one hand and emphasizes the significance of rituals for the

* Submitted: 29/01/2019; peer-reviewed: 15/04/2019; accepted: 16/04/2019. Blessing O. Boloje, "Extravagant Rituals or Ethical Religion (Micah 6:6-8)? Ritual Interface with Social Responsibility in Micah," Old Testament Essays 32 no. 3 (2019): 800 - 820. DOI: https://doi.org/10.17159/2312-3621/2019/v32n3a3.

1 This article forms part of author's current research project on "The nexus between ethics and socio-economic actuality in Micah," at Ruhr-Universität Bochum, Germany. 2 The term "ritual" is used to designate a recommended order for the performance of religious or devoted duties. In OT scholarship, it is a general label for offerings, sacrifices and related activities. Bohdan Hrobon, Ethical dimension of the cult in the book of Isaiah (Beihefte zur Zeitschrift fur die Alttestamentliche Wissenschaft 418; De Gruyter: Berlin/New York, 2010), 6. 
improvement of ethical life of people in covenant community and society on the other hand. ${ }^{3}$ As an essential domain of both private and public worship, the cult ${ }^{4}$ plays a vital role in the religious life of ancient Israelite community. ${ }^{5}$ Israel's cult is conceived as direct witness to and epitome of the dynamic practice of intimacy with Yahweh (in his very essence and character as sovereign and gracious). This dynamic relationship obviously becomes not only a necessary support for ethical intentions but a testimony about one who behaves in an ethical manner. Consequently, the prophetic polemics about the cult becomes very pointed when there is an imbalance in the divine-human relationship. ${ }^{6}$ The rhetorical features that one finds in cult critical texts are those that compel the audience and/or readers to focus on the significance of ethical behaviour of ritual practitioners. ${ }^{7}$

Employing different strategies and theological methodologies to the situations of their time, prophets such as Amos, Hosea and Isaiah speak with a vehemence of interest regarding the inseparable connection between cult (rituals) and ethics. Their criticism does not categorically denounce cultic and/or ritual actions, the decency of the sacrifices, or even the devoutness with which the sacrifices are offered. Rather, these prophets enthusiastically criticize the absence of moral integrity in the lives of the worshippers (cf. Amos 5:21-24; 8.4-6; Hos 4:4-6; 6:1-6; Isa 1:10-17). They decried and denounced a superciliously blossoming and extravagant cult, but such that was bereft of any sense of social obligations towards the weak and helpless within the society. ${ }^{8}$ Thus they charged the people not only to perform rituals but to embody their performance of rituals with suitable, sustainable, healthy, merciful and ethical attitudes toward one another. Such appropriate ethical behaviour helps to define the cult/rituals as either viable or outrageous. ${ }^{9}$

3 John Barton, "The Prophets and the Cult," in Temple and Worship in Biblical Israel. Proceedings of the Oxford Old Testament Seminar (ed., John Day; New York: T\&T Clark, 2007), 111-112.

4 All forms of ritual activities, whether public or private that are connected with homage to a deity, are treated under the term cult. Roland de Vaux, Ancient Israel: Its Life and Institutions (trans., John McHugh, The Biblical Resource Series 3; Grand Rapids, MI: Eerdmans, 1997), 271.

5 Walter Brueggemann, Theology of the Old Testament: Testimony, Dispute, and Advocacy (Minneapolis: Fortress Press, 1997), 650.

6 Brueggemann, Theology of the Old Testament, 678.

7 Hrobon, Ethical dimension of the cult in the book of Isaiah, 10.

$8 \quad$ Rick R. Marrs, "Micah and a Theological Critique of Worship," Worship and the Hebrew Bible: Essays in Honour of John T. Willis (eds., M. P. Graham, R. R. Marrs and S. L. McKenzie, JSOT Supplement Series 284; Sheffield: Sheffield Academic Press, 1999), 184-203 (184).

9 Theresa V. Lafferty, The Prophetic Critique of the Priority of the Cult: A Study of Amos 5:21-24 and Isaiah 1:10-17 (Parkway: UMI Dissertation Publishing, 2010), 13. 
These prophets are well known for their efforts to right the discrepancy in Israelite religion that focuses on the significance of rituals but diminished the necessity of morality. In their midst, however, is a relatively less-known but obviously very persuasive Micah. In the book of Micah, rituals are presented as expressions of people's relationship with Yahweh (worship, offering and sacrifices) that do not impact positively on the horizontal dimension (social responsibility). This imbalance of relationship is poignantly addressed by Micah as his oracle switches from confrontation to reconciliation. The confrontation begins with a summons $(6: 1)$, indictments or interrogation of the accused $(6: 2-$ $3)$, recitation of Yahweh's (6:4-5), rejection of extravagant rituals as means of reconciliation $(6: 6-7)$, and a verdict that is sketched out by the crowning verse (6:8); fittingly regarded and celebrated as the ultimate definition of ethical religion and as one of the supreme ethical discoveries of the history of religion. This article addresses the confrontation between Yahweh and Israel/Judah by juxtaposing two dominant spheres of Israel/Judah's religious life; ritual and lifestyle. The article holds that a truly ethical religion is not about extravagant rituals but personal duty and responsibility for fulfilling that duty in society. In the following sections, the article explores the literary portrayer of the prophetic character of Micah and his relative historical context. It attempts to determine the literary context, literary feature and structure of Micah 6:6-8 before analysing the particular passage that is germane to an understanding of Israel/Judah's ritual and ethical life. Micah 6:6-8 stands in sharp contrast to the extravagance and mockery of rituals and as an alternative presents a message most profound and insightful for an invaluable decision.

\section{B LITERARY PORTRAYER OF MICAH AND HIS HISTORICAL CONTEXT}

The name Micah is set as the eponymous prophet of the book of Micah. It is a shortened form, ${ }^{10}$ whose meaning is a rhetorical question: "who is like Yahweh?" The canonical book itself has for several decades been a battlefield for critical scholarship, with two key questions dominating the debate namely; issue of origin and final shape of the book. In attempts to answer these questions, the literary-critical methodology has been used by scholars. Literary, historical and theological criteria on the one hand, attempts to determine what was original to the prophet and what came from other and later hands. On the other hand, the form and redaction-critical methodology focuses on the final shape of the book. These approaches have led to the search for and evaluation of the different

10 Jeremiah 26:18 alternates between the short form (מִיכָ) in Micah 1:1 and the long form (מִיכָיָָ) in 2 Chronicles 13:2. In this article, the name Micah implies the literary prophetic image of the character presented set as the eponymous prophet of the Book of Micah. 
traditional points of view represented in different layers of the book. ${ }^{11}$ Micah's name stresses the transcendence and incomparability of Yahweh; who is concerned with and committed to existential matters of human reality. ${ }^{12} \mathrm{He}$ was known by his hometown Moresheth (1:1, 14; cf Jer 26:17-18), probably identified with Moresheth-Gath, ${ }^{13}$ and situated as it was in the lowlands between the Philistine plain on the west and the Central Mountain Range on the east, in the south-western part of Judah. ${ }^{14}$

Micah's genealogy or parentage and original occupation are unknown. Consequently, the spectrum of speculation becomes inevitable. ${ }^{15}$ He must have been from the tribe of Judah since his hometown is situated in the territory of Judah. His identification with his hometown rather than his parentage in the opening verses suggests that he was regarded as an outsider by his contemporaries with whom he ministered in the Judean territories of Jerusalem. Some interpreters hold that he was not a professional prophet, ${ }^{16}$ but a leader of a revolutionary movement ${ }^{17}$ and a Levite or dissident priest. ${ }^{18} \mathrm{He}$ was probably a farmer in the agrarian community of Moresheth, since he is familiar with and utilizes imageries common to farming. ${ }^{19}$ According to Stephen G. Dempster, "He

11 Rex Mason, Micah, Nahum, and Obadiah (New York: T\&T Clark International, 2004), 27. In a previous article, I addressed issues on the debate regarding structure, approaches and unity of the book of Micah. See B.O. Boloje, "Micah's Theory of the Justice of Judgement (Micah 3:1-12), J Journal for Semitics 26/2 (2017):689-710 (693697).

12 James L. Mays, Micah: A Commentary (London: SCM Press Ltd., 1976), 1; Stephen G. Dempster, Micah (The Two Horizons Old Testament Commentary; Grand Rapids, Michigan: William B. Eerdmans Publishing Company, 2017), 2.

13 Francis I. Andersen and David Noel Freedman hold that the name was assigned to Jerusalem, probably as a "derogatory" term employed by the city-dweller to refer to the "rustic." Francis I. Andersen and D. N. Freedman, Micah: A New Translation with Introduction and Commentary (AB 24E; New York: Doubleday, 2000), 109.

14 Philip J. King, Amos, Hosea, Micah-An Archaeological Commentary (Philadelphia: The Westminster Press, 1988), 60; John H. Walton, Victor H. Matthews and Mark W. Chavalas, eds., The IVP Bible Background Commentary Old Testament (Downers Grove: Inter-Varsity Press, 2000), 780-81.

15 Delbert R. Hillers, Micah: A Commentary on the Book of the Prophet Micah (Philadelphia: Fortress Press, 1984), 14; Mays, Micah, 15.

16 See Joseph Blenkinsopp, A History of Prophecy in Israel (Louisville: Westminster John Knox Press, 1996), 95; Ralph L. Smith, Micah-Malachi: Word Biblical Commentary 32 (Waco: Word Books, 1984), 4; Bruce V. Malchow, "The Rural Prophet: Micah," Currents in Theology and Mission 7 (1980): 48-52 (48).

17 David Pawson, Unlocking the Bible: A Unique Overview of the Whole Bible (London: Collins, 2003), 525.

18 Juan I. Alfaro, Micah: Justice and Loyalty (Grand Rapids: Eerdmans, 1996), 4.

19 His many references to agricultural imageries indicate his familiarisation with agricultural economy or personal knowledge of land, farming, crops and animals production: the plantings of a vineyard (1:6), lamenting like the jackals and mourning 
certainly identified with the members of his village whose small farms were being swallowed up by wealthy landowners (2:1-4)." ${ }^{20} \mathrm{H}$.W. Wolff holds that Micah was a leading Moresheth city councilman or elder who served as an advocate of justice for his people, presenting the plights of the peasant farmers and poor to the rich and influential in Jerusalem. This might also account for his literacy (cf. Mic 3:1). ${ }^{21}$

The general historical context, of course, of his prophetic ministry is indicated by the historical superscription (1:1), during the reigns of kings of Judah, namely Jotham, Ahaz, and Hezekiah. ${ }^{22}$ These kings are, however, not explicitly mentioned by Micah in his documented oracles. ${ }^{23}$ While the historical superscription indicates the significance of history in understanding the biblical message of Micah, it is very instructive to observe that the book omits reference to the northern kings of Israel in its chronology. ${ }^{24}$ Certainly, the address of Micah's message clearly states Samaria and Jerusalem (1:1) and the first oracle directly refers to Samaria (1:2-7). Micah's oracle (6:9-16) with reference to the

like the ostriches (1: 8), the baldness of the eagle (1:16), fields and homes (2:2-4), the ploughing of field (3:12), the beating of swords into ploughshares, and spears into pruning hooks (4:3), fig tree and vine (4:4), the gathering of sheaves to the threshing floor (4:12), the dew and rain on plants (5:7), a lion among sheep; sowing and reaping ( 6:15), treading olives and grapes (6:15), the picking of fruit, grapes, and figs (7:1), the briars as hedges (7:4), and the extension of fields' boundary markers (7:11).

20 Dempster, Micah, 6; Pawson, Unlocking the Bible, 525.

21 Hans Walter Wolff, Micah: A Commentary (trans., Gary Stansell; Minneapolis: Augsburg Fortress, 1990), 6-7. See also, Eric A. Mitchell, "Micah - The Man and His Times," Southwestern Journal of Theology 46 (2003): 57-76 (67).

22 D. N. Premnath, "Amos and Hosea: Sociohistorical Background and Prophetic Critique," Word \& World 28/ 2 (2008): 125-132 (126); James D. Nogalski, The Book of the Twelve: Micah-Malachi (Macon, Georgia: Smyth \& Helwys Publishing, Inc., 2011), 511. Micah is identified as a younger contemporary of Isaiah (Isa 1:1), both of whom prophesied in Jerusalem and Judah, the home of royal and Zion theology. David M. Carr, An Introduction to the Old Testament: Sacred Texts and Imperial Contexts of the Hebrew Bible (Chichester: John Wiley \& Sons Ltd., 2010), 117. From the theological perspective of Deuteronomistic editors, " $1-2 \mathrm{Kgs}$ evaluates rulers on how faithfully they promote exclusive worship of YHWH in Jerusalem: Jotham receives positive marks, even though people worshiped at 'high places' (e.g., 1 Kgs 14:22-23); Ahaz is judged as idolatrous ( $2 \mathrm{Kgs} 16$ ); and Hezekiah is praised for destroying worship sites outside Jerusalem (2 Kgs 18:4-5).” J. M. O’Brien, Micah (Wisdom Commentary 37; Collegeville, Minnesota: Michael Glazier Book, 2015), 2.

23 Dempster, Micah, 9.

24 Prophetic editors normally omitted reference to the northern kings from the historical superscriptions, especially for the prophets of the southern kingdom. Sometimes a northern king will be mentioned for prophets of the northern kingdom, following a long dynastic reign, but only after the relevant kings of Judah (Hos 1:1; Am 1:1). The only obvious evidence of the mention of a northern king is Jeroboam II, who essentially completed a dynasty of Jehu that was sanctioned by the prophets. Dempster, Micah, 62 . 
statutes of Omri and the counsels of the house of Ahab is more relevant to the northern kingdom than to the southern. Obviously, Micah's major concern was Judah and Jerusalem, and the presence of Samaria in the final version of the book serves as a powerful warning to Judah. ${ }^{25}$ The uniqueness of Micah's prophecy is seen in his application of the historical lesions of the fate of Samaria $(1: 1,5-7)$ to the reality of Judah and Jerusalem $(1: 5,9 ; 3: 9-12)$.

The major political events that shaped the backdrop to Micah's ministry are found in the records of 2 Kings 15-19. These texts show that these kings functioned during the eighth-century Neo-Assyrian political and ideological dominance of the ANE. ${ }^{26}$ They relate various Assyrian swipes on the region including the capture of Samaria in 722/721 BCE and the siege of Jerusalem in $701 \mathrm{BCE}^{27}$ In light of the general historical constraints indicated in the opening verse, there is obviously some liberty for establishing precise time frame for Micah's oracles. If Micah's prophetic ministry began at the beginning of Jotham's reign immediately after his father's death (742 BCE) to the close of Hezekiah's reign $(687 \mathrm{BCE})$, this would be a maximum period of fifty-five years. The minimum years, would be in the last years of Jotham until the first year of the reign of Hezekiah, which would be about twenty-two years. However, the natural context for many of Micah's oracles, especially his judgment oracles (1:8-16; 3:912), most likely should extend until shortly after the Assyrian crisis around 701 BCE, thus consisting of a period of nearly thirty-five years. ${ }^{28}$ Micah addresses a distinctive aspect of society and of political situation and life. The oracles are seen against the background of a community in which the citizens are under authority. Consequently, its political structure can only be examined by paying attention to the events that shaped the life of the community under authority. ${ }^{29}$

\section{LITERARY CONTEXT, FEATURE AND STRUCTURE OF MICAH 6:6-8}

Micah 6:6-8 is a sub-unit of 6:1-8 that falls within the third movement section $(6-7)$ in the book of Micah. ${ }^{30}$ In its literary context, this didactic dialogue unit

\footnotetext{
25 Dempster, Micah, 63.

26 Donald E. Gowan, Theology of the Prophetic Books: The Death and Resurrection of Israel (Louisville: Westminster John Knox Press, 1998), 50; Iain Provan, V. Philips Long and Tremper Longman III, A Biblical History of Israel (Louisville: Westminster John Knox Press, 2003), 271-273.

27 O'Brien, Micah, 2.

28 Dempster, Micah, 61.

29 David J. Reimer, "The Prophet Micah and Political Society," in Thus Speaks Ishtar of Arbela: Prophecy in Israel, Assyria, and Egypt in the Neo-Assyrian Period (eds., Robert P. Gordon and Hans M. Barstad; Winona Lake, Indiana: Eisenbrauns, 2013), 203-224 (211).

30 Various arguments exist in Micah studies regarding the structure of the book. Kenneth H. Cuffey underscores a four-fold structural division: 1:2-2:13; 3:1-4:8; 4:9-
} 
$(6: 1-8)$ is not specifically anchored in the world of the text to any particular settings, place, time, and location. ${ }^{31}$ Thus like the rest of other units in the book of Micah, the reading falls within an eighth century setting that assumes knowledge of Judah's story on several levels as well as evoke echoes of the looming Assyrian invasion. ${ }^{32}$ The oracle was probably first delivered at a temple where a larger number of worshippers were gathered, as it is an indictment of them and not about specific leaders. Illuminating the probability that the prophet presented this oracle in the sanctuary at Jerusalem are, Torah teachings with its sacred history, pronouncements of priests, the fragrance of sacrifices and the call to an ethical life. One can imagine the Assyrian crisis of $701 \mathrm{BCE}$ while the people were attempting to make atonement for their transgressions. ${ }^{33}$ Concerning the didactic thrust of the unit, Wolff makes this remark, "A didactic sermon-inoutline, the passage leads the reader from the present reality of Yahweh's great deeds of salvation, through a discussion of inappropriate cultic responses, and then on to clear statements of "what is good' for human beings." 34

A hypothetical priestly or more precisely a liturgical textual setting could be envisaged as an antecedent of 6:1-8. Thus the close relationship of this unit with the cult indicates that the oracle "derives from temple ceremonial 'in einer kultischen Gerichtszene'." ${ }^{35}$ In his form critical interpretation of Micah 6:1-8, Paul L. Watson submits that the Sitz im Leben of the unit is probably, where

5:14; and 6:1-7:20. Kenneth H. Cuffey, "The Coherence of Micah: A review of Proposals and a New Interpretation" (DPhil. dissertation, Drew University, 1987), 301304. Advocates of a three-fold division: the book of doom (1:2-3:12); the book of vision (4:1-5:14); the book of contention and conciliation (6:1-7:20) includes, Andersen and Freedman, Micah, 7-14; Walter Brueggemann, An introduction to the Old Testament: The Canon and Christian Imagination (Louisville, KY: Westminster John Knox, 2003), 234-235; Bruce K. Waltke, "Micah," in The Minor Prophets: An Exegetical and Expositional Commentary (ed., Thomas Edward McComiskey; Grand Rapids: Baker Books, 1998), 591-764 (594). Still there are those in favour of two distinct two-fold divisions: Micah1-5 and 6-7; or 1-3 and 4-7. See Daniel L. SmithChristopher, Micah: A Commentary (OTL; Louisville, Kentucky: Westminster John Knox Press, 2015), 33. See also Jacob Mignon, The Conceptual Coherence of the Book of Micah (JSOTSup 322; Sheffield: Sheffield Academic Press, 2001), 62-63. See also, Leslie C. Allen, The Books of Joel, Obadiah, Jonah, and Micah, NICOT (Grand Rapids: Eerdmans, 1976), 260-261; Kenneth L. Barker, "A Literary Analysis of the Book of Micah," Bibliotheca Sacra 155 (1998): 437-441; Bruce K. Waltke, A Commentary on Micah (Grand Rapids: Eerdmans, 2007), 14.

31 Ehud Ben Zvi, Micah (Forms of the Old Testament Literature 21B; Grand Rapids: Eerdmans, 2000), 151.

32 Daniel J. Simundson, Hosea, Joel, Amos, Obadiah, Jonah, Micah (Abington Old Testament Commentaries; Nashville: Abington Press, 2005), 338

33 Dempster, Micah, 162.

34 Wolff, Micah: A Commentary, 183.

35 Andersen and Freedman, Micah, 509. 
priests assemble in judgment of cases that deal with the questions of the covenant and the cult and where, as judges in a trial, they are expected to pronounce the judgment in a manner that is traditional to the priestly office. ${ }^{36}$ The setting-inlife assumed by the style indicates a situation in which a sinner, conscious of his predicament because of sin which endangers his relationship with God and familiar with the fact that a sacrifice of atonement is a basic requirement, seeks to receive direction as to what is adequate. ${ }^{37}$ Although the sphere of competence and influence to which the question is directed is the responsibility of the priest, "the language in these verses cannot be characterized as priestly . . . there are no reference to entering the temple, nor to anyone wishing to enter a temple; . . . the basic structure of the entrance liturgies consists of question, response, and promise (cf. Pss 15:1-5; 24:3-4; Isa 33:14b-16); there is no such promise in Mic 6:6-8." ${ }^{38}$ However, it is challenging to keep the intensely personal and dynamic relationship between Yahweh and Israel within a legalistic and covenantal framework giving the consideration of formal justice. There is a conflict between the legal background that provides some of the ideas and vocabularies for the dispute and the more literary expression of the emotional and interpersonal aspects of the covenant in the drama of the unit. ${ }^{39}$

The unit illuminates the world of knowledge of the audience and readers. Accordingly, the audience of the book is imagined as being familiar to some foundational traditions of Israel; the exodus from Egypt, the Balak-Balaam story, and the crossing of the Jordan. They were also aware of the literary as well as theological and didactic routine of the supremacy of morality over rituals. This is not to say that supremacy as understood was that rituals had no significance; rather, ritual performances in the midst of covenant faithlessness have no value. ${ }^{40}$ The sub-unit (6:6-8) raises and addresses fundamental questions which are vital not only to those on trial, but to adherents of biblical faith throughout history. In it, the voice of the prophet confronts the nation and people at every level with accusations that their own inattentiveness to Yahweh's demands; of (justice), חֶֶד (mercy, kindness), and humility before God (6:8), has endangered the land to a degree that Yahweh can no longer ignore. ${ }^{41}$ Thus it stresses a call to repentance and renewal.

A majority of scholarly opinions hold that the unit (6:1-8) is constructed in order to evoke the images and associations of a covenant lawsuit, a manifest

36 Paul L. Watson, "Form Criticism and an Exegesis of Micah 6:1-8." Restoration Quarterly (1963): 61-72 (64).

37 Mays, Micah: A Commentary, 137.

38 Ben Zvi, Micah, 151.

39 Andersen and Freedman, Micah, 507.

40 Ben Zvi, Micah, 152.

41 Nogalski, The Book of the Twelve: Micah-Malachi, 580. 
example of the so-called $r i ̂ b$ form (appearing 3 times in $6: 1-2) .{ }^{42}$ Consequently, J. Carl Laney remarks that Micah 6:1-8 is an illustration of juridical procedures for dealing with covenant violation "brought by a messenger (a prophet) against the vassals (the people of Israel) for their violation of their treaty (the Mosaic covenant) with the Great Suzerain (Yahweh)." ${ }^{\prime 3}$ Although, this literary form has been mostly accepted as it allows readers to interpret the text with limited difficulties, it is however observed that Micah does not use one specific literary genre for each separate oracle unit. In fact, he scarcely uses a piece in line with the literary and social conventions that govern the normal function of its literary genre. ${ }^{44}$ Commenting on the inconsistency of Micah's use of genre, Ronald T. Hyman observes, "Complexity and some confusion arise because Micah does not follow the lawsuit analogy to its fullest and does not identify the speakers explicitly while he himself speaks all the roles within the dramatic analogy."45

Surprisingly, one can observe that Yahweh's role in this lawsuit analogy is subverted in the unit. Usually, Yahweh is expected to be either the prosecuting attorney or judge. As an alternative, Yahweh plays the role of the aggrieved petitioner appearing before an anonymous prosecuting attorney or judge. ${ }^{46}$ In study of the form and interpretation of Micah 6:1-8, the unit shares, like Isaiah 5:1-7 the rhetorical use of interrogation. Both include a recitation of the benevolent actions of Yahweh. In line with Isaiah who begins his poem by giving it a title that stimulates the expectation that it will be a love song and then faces other directions, so Micah opens the unit with a covenant lawsuit ( $r \hat{\imath} b$ ) and then betrays the usual procedure for such an adventure. ${ }^{47}$ As it stands, the literary background of the constituents of Micah $6: 1-8$ is diverse; as an artistic composition, the unit seems to be a mix of literary features. At its opening, the unit does evoke the mental image of legal procedures (6:1-3). Micah utilizes wordplay in the invocation to the mountains and hills to be the intimate witness to the proceedings. ${ }^{48}$ The rhetoric of verses $4-5$ demonstrates creedal recitation

42 A covenant dispute is conducted as a lawsuit in which indictments are brought on the people of Israel by Yahweh over breaches of various covenant requirements (cf. Deut 32:1-43; Ps 50; Isa 1:2-3, Jer 2:2-37; Judg 10:11-14). Herbert B. Huffmon, "Covenant Lawsuit in the Prophets," Journal of Biblical Literature 78 (1959): 285295 (285, 295); Ronald T. Hyman, "Questions and Response in Micah 6:6-8," Jewish Bible Quarterly 33/ 3 (2005): 157-165 (158); J. Carl Laney, "The Role of the Prophets in God's Case against Israel," Bibliotheca Sacra 138 (1981): 313-325 (321); Timothy M. Pierce, "Micah as a Case Study for Preaching and Teaching the Prophets," Southwestern Journal of Theology 46/1 (2003): 77-94 (83).

43 Laney, "The Role of the Prophets in God's Case against Israel," 323.

44 Andersen and Freedman, Micah, 508.

45 Hyman, "Questions and Response in Micah 6:6-8," 158.

46 Ben Zvi, Micah, 148-149; Watson, "Form Criticism and an Exegesis of Micah $6: 1-8, " 70$.

47 Andersen and Freedman, Micah, 508.

48 Waltke, A Commentary on Micah, 375. 
of Yahweh's mighty deeds. In fact, Yahweh's covenant faithfulness led to Israel's liberation rather than bondage, but on the contrary Israel turned its faith back into bondage. ${ }^{49}$ The legal procedure is continued with further interrogations about requirements of true worship. These questions of truly ethical religion have given rise to the proposal that 6:6-8 reflects the genre of or belongs to the cult; a temple entrance ritual or a priestly Torah liturgy (cf. Pss 15:1-5; 24:3-6; Isa $33: 14 \mathrm{~b}-16){ }^{50}$

Although one can observe a sharp difference between the legal character of $6: 1-5$ and the cultic/priestly nature of $6: 6-8,{ }^{51}$ the kerygmatic equilibrium between 6:1-5 and 6:6-8 binds the two sub-units closely together. ${ }^{52}$ Micah 6:15 is relatively incomplete and abridged without the concluding questions in escalating importance exemplifying Judah's distorted theology of worship and answers presented in intensifying significance about ethical religion. ${ }^{53}$ The disputation begins with a summons $(6: 1)$, indictments or interrogation of the accused (6:2-3), recitation of Yahweh's deeds (6:4-5), rejection of extravagant rituals as means of reconciliation (6:6-7), and a verdict that is sketched out by the crowning verse $(6: 8)$. The constituent literary structure of the unit $(6: 1-8)$ is presented below. ${ }^{54}$
A. Call for attention (6:1a)
B. Commissioning of the prophet (1b)
C. Invocation of inanimate witnesses of Israel's actions (1b-2a)
D. Yahweh's questions: Israel's indebtedness to Yahweh (3-5)
a. Initial question (3)
b. Yahweh liberation of Israel and Israel's benefits Yahweh's actions (4)
c. Address that stresses a need to repentance (5)

E. Israel's response with questions pertaining to true worship (6-7)

a. First rhetorical question: Implicit admission of guilt (6a)

b. Escalating question exemplifying Judah's distorted theology of worship (6b-7)

1. Second rhetorical question: Quality (6b)

2. Third rhetorical question: Quantity (7a)

3. Fourth rhetorical question: Desperation (7b)

\footnotetext{
49 Dempster, Micah, 154.

50 Andersen and Freedman, Micah, 510; Ben Zvi, Micah, 150; Wolff, Micah, 167.

51 May observes that the two appear to be quite distinct literary types with no clear example elsewhere in the OT of this kind of mixture in a disputational, didactic rhetorical unit. Mays, Micah: A Commentary, 138.

52 William McKane, Micah: Introduction and Commentary (Edinburgh: T. \& T. Clark, 1998), 177-179.

53 Hillers, Micah, 77; Dempster, Micah, 155.

54 I have followed Laney, "The Role of the Prophets in God's Case against Israel," 322; and Dempster, Micah, 155, here with modifications.
} 
F. Yahweh's verdict and remedy (8)

a. The verdict: You have been told already (8a)

b. The remedy: Three compact answers in intensifying significance (8b)

1. First answer highlights the necessary action: To act justly

2. Second answer accentuates inner attitude of solidarity: To love kindness

3. Third answer stresses the wellspring of both actions: To walk humbly (live cautiously) with your God

In view of the scope of this article, the subsequent sections analyse the two dominant spheres of Israel/Judah's religious life; ritual and lifestyle with a view to explicating the fundamental issues of a truly ethical religion.

\section{ANALYSIS OF THE TWO DOMINANT SPHERES OF ISRAEL/JUDAH'S RELIGIOUS LIFE (MICAH 6:6-8)}

Micah 6:6-8 is clearly a theological and didactic response of Israel's to Yahweh's questions in 6:3-5 and Yahweh's verdict that defines a truly ethical faith; namely, the supremacy of morality over rituals. In the drama of the text, the unidentified speaker, who responds to Yahweh's questions, represents Israel. ${ }^{55}$ The following sub-sections present a literary analysis expressing both the intensely emotional and dynamic interpersonal aspects of the covenant relationship between Yahweh and Israel.

\section{Extravagant Rituals as means of Reconciliation (6:6-7)}

6:6 With what shall I come to the LORD

(With what) shall I bow before the God on high?

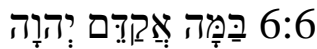

Shall I come to Him with burnt offerings, With yearling calves?

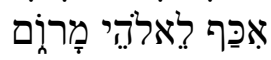

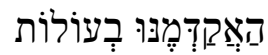

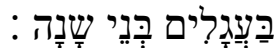

6:7 Does the LORD take delight in thousands of rams, In ten thousand rivers of oil?

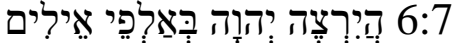

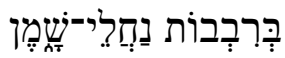

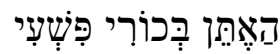
Shall I present my first-born for my rebellious acts, the fruit of my body for the sin of my soul?

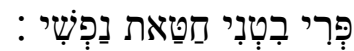

The central issue that is hanging in the balance between Yahweh and Israel is essentially that of relationship that requires immediate attention. The word wָ (what) used repeatedly in 6:3, 5, 6,8 underscores the dialogical character of what the questions and issues requiring attention by both Yahweh and the people are. ${ }^{56}$ In the opening legal section $(6: 1-5)$, Micah provides a vision of

55 Mays, Micah: A Commentary, 137.

56 Philip P. Jenson, Obadiah, Jonah, Micah: A Theological Commentary (LHBOTS 496; New York; T \&T Clark, 2008), 167. 
who Yahweh truly is to Israel. Yahweh compellingly declares his case and protests his guiltlessness regarding any form of wrongful behaviour in his relationship with Israel. This is aptly captured in his redemptive deeds on behalf of Israel (6:3-5). Most interestingly, Yahweh's redemptive acts demonstrate his right behaviour and commitment towards Israel and the essence of his being. According to Rick R. Marrs, "The recitation is vivid and compressed. Four emphases appear: redemption from Egypt, inspired leadership (Moses, Aaron, Miriam), deliverance from the schemes of Balak and Balaam, entrance into the land." 57

While Yahweh's questions to Israel function in reality as declarations of guiltlessness, the switch from the recitation of Yahweh's saving deeds (6:3-5) to the response of the people $(6: 6-7)$ is obviously abrupt. The opening interrogative, (with what) in verse 6 introduces a lame defense that is highly illogical. ${ }^{58}$ The rhetorical question indicates the procedure which the interrogator believes he must follow (cf. Gen 15:8; Ex 23:15; 1 Sam 6:2; 2 Sam 21:3). It is based on a specific assumption and orientation that focuses on the possibilities which that assumption allows. In dealing with Yahweh, the response of the speaker implies that Yahweh is in fact the problem. The response grows out of textual orientation such as ". . . none shall appear before me empty-handed" (Ex $23: 15 ; 34: 20)$ in Israel normative tradition and was strengthened by a growing significance of cultic sacrifice in Israel's religious development. ${ }^{59}$ With the

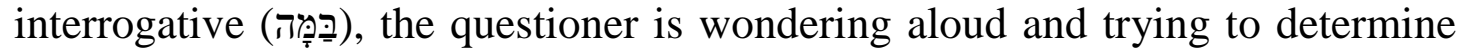
what is required and adequate to enter into Yahweh's presence; namely "to meet

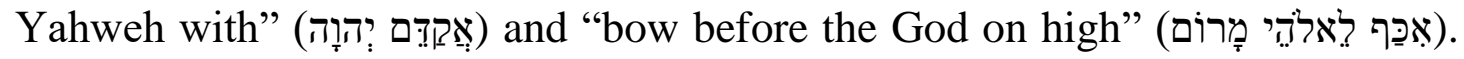
Access to Yahweh's presence by an individual or group usually requires various forms of speech, and Israel's three great annual festivals (Ex 23:10-19; 34:18-26; Deut 16:1-17; Lev 23:4-44; Num 28-29) show that the major features of Israel's worship are great offering of sacrifices. ${ }^{60}$

57 Rick R. Marrs, "Micah and a Theological Critique of Worship," Worship and the Hebrew Bible: Essays in Honour of John T. Willis (eds., M. P. Graham, R. R. Marrs \& S. L. McKenzie, JSOT Supplement Series 284; Sheffield: Sheffield Academic Press, 1999), 184-203 (201).

58 Marrs states that, “. . . the startling 'with what shall I come before the Lord. . ' (במה) counters Yahweh's earlier questions ('What have I done to you? In what have I

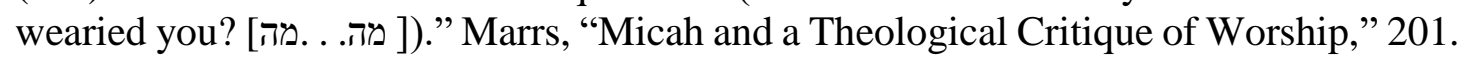
59 Mays, Micah: A Commentary, 139.

60 For a mode of access into Yahweh's presence see, Patrick D. Miller, They Cried to the Lord: The Form and Theology of Biblical Prayer (Minneapolis: Augsburg Press, 1994), 46-49; Danijel Berković, "Aspects and Modalities of God's Presence in the Old Testament," KAIROS - Evangelical Journal of Theology III/1 (2009): 51-72; John Kessler, Old Testament Theology: Divine call and Human Response (Waco, Texas: Baylor University Press, 2013), 382, 398. 
Since coming before Yahweh imagines the shrine where he is present and where sacrifices can be accepted, the verbs in verse 6 characterize the approach not in the usual manner but in a highly particular way. The first two phrases "to

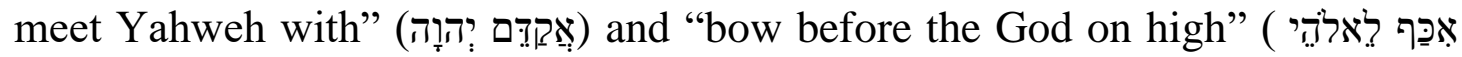
(מָרוֹם ) demonstrate both parallelism and progression. The verb (קָבָם preposition (ב) ( ) in verse 6 , evokes the picture of an approach to someone else with gifts meant to achieve a complimentary reception and approval (cf. the story of Jacob's preparation to meet Esau in Gen 32:13ff; in a cultic context, Ps 95:2). ${ }^{61}$ The image of prostration and adoration is also very striking. The Niphal verb (bow down) in other contexts indicates bowing down in distress, oppression and humiliation (Pss $57: 7 ; 145: 14 ; 146: 8$ ). The uniqueness of the form in this verse suggests a reflexive meaning "bow myself down." 62 The self-abasement is a way of acknowledging and confessing the absolute sovereignty of Yahweh; who in the imagination of the inquirer is unreachable (לאלהי מָרוֹם - God on high). Here, מָּר distressed (Pss 7:8; 18:17; 68:19; 144:7; Isa 58:4; Lam 4:13). ${ }^{63}$

Verses $6 b-7$ continue to unfold a litany of possible "adequate" offerings. The list does not suggest ethical or social justice rhetoric but it ranges across a spectrum of sacrificial offerings and is comprehensive in its descriptive character. The sequence of the response indicates an ascending intensity from quality, quantity, to the unimaginable offerings (child sacrifice). The list obviously exhausts the available possibilities in realm and practice of sacrifice and leaves no stone unturned in the search for what is adequate enough to achieve reconciliation with Yahweh. The first sacrifice is that of quality: "Shall I come

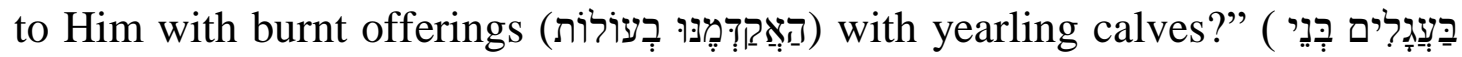

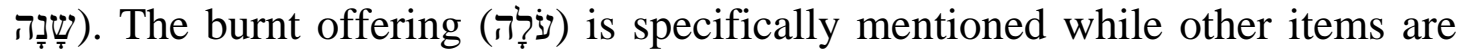

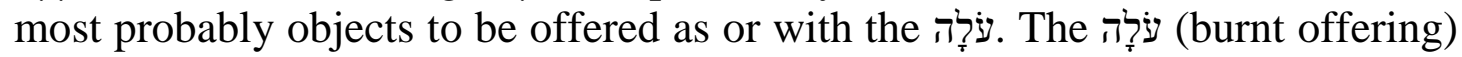
was a sacrifice totally dedicated to God, with no share for the worshipper. It is proposed as a gift and its primary purpose is to deal with sin. While a calf was adequate for sacrificial purpose after eight days old; a yearling calf would be more expensive than most individual offerings (Lev 9:3; 22:27). ${ }^{64}$

The verb רָצָה (to be pleased) in verse 7 is a technical term in priestly text for the acceptance of a sacrifice by Yahweh (Lev 1:4). It is used elsewhere to indicate that sacrifice is inseparable from the life it represents (Lev 1:4; 22:23; 2 Sam 24:23; Jer 14:10-14). רָָָה illustrates a hint of Yahweh's delight and approval in an honest sacrifice (cf. Ps 51:18; Mal 1:10). However, the speaker's

61 Mays, Micah: A Commentary, 139.

62 Dempster, Micah, 159.

63 Jenson, Obadiah, Jonah, Micah, 171; Mays, Micah: A Commentary, 139; Andersen and Freedman, Micah, 524.

64 Hillers, Micah, 78; Mays, Micah: A Commentary, 140; Andersen and Freedman, Micah, 525. 
critical tone in the intensification of the proposal with a second consideration of quantity "reverses the intended assurance of acceptance, suggesting instead an impossible level of demand." ${ }^{65}$ Rams and oil appear in other sacrificial acts (Lev

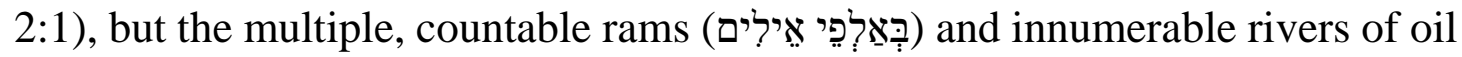
to be poured upon the sacrificial altar and raise the value of the sacrifice (Ex 29:2), are of course deliberately fanciful. ${ }^{66}$

The list of alternatives and possibilities reaches its pinnacle of human

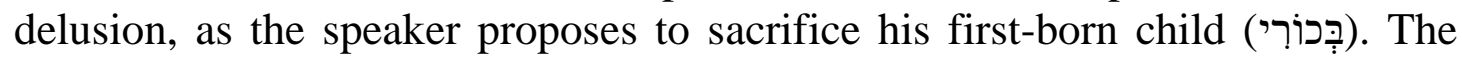

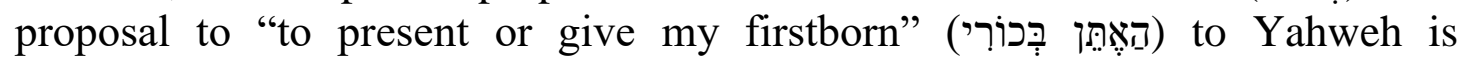
astonishing. Yahweh's claim of the first born is well articulated in Israel's normative tradition and redemption is to be made by a substitute offering (Ex $13: 2 ; 22: 28 ; 34: 20)$. Although reported cases of human sacrifice in Israel are rare and are told as exceptional cases (cf. Lev 20:2-5; Judg 11:30-40; 2 Kgs 3:27; $16: 3 ; 17: 17 ; 21: 6 ; 23: 10 ;$ Jer $7: 31 ; 19: 5)$, the practice is strictly prohibited in Israel (Deut 12:31; 18:10; Lev 18:21; 20:2-5). ${ }^{67}$ The proposal does not draw from any recognized spectrum of possibilities in the cultic tradition of Israel. Thus far from being an extravagant evidence of piety, it defiled the primary, most essential moral and religious norms of Israel.

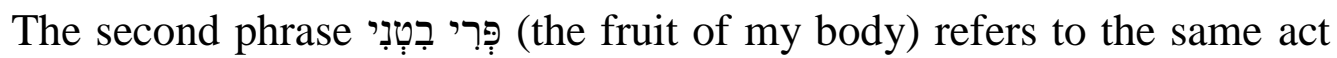
but escalates through the use of a minimal metaphor (cf. Deut 30:9). ${ }^{68}$ The necessity of offerings lies in guilt before Yahweh. In the later part of verse 7, the

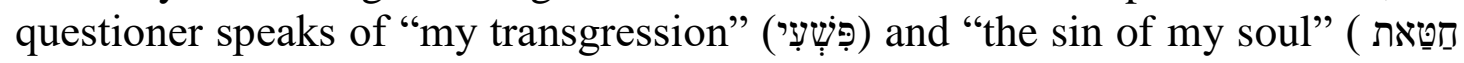

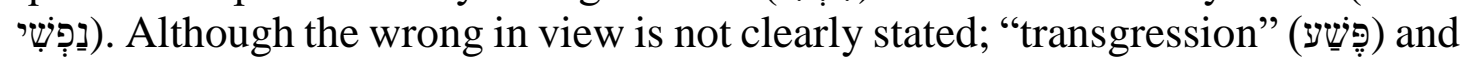
"sin" (חסטָטאת) are synonymous pairs that are used as general category for acts that violate Yahweh's norms for the sacral and social spheres (cf. Mic 1:5; 3:8; 7:18; Ps 54:4). What is clear is that all who fall into this category as sinners needed reconciliation with Yahweh. ${ }^{69}$ However, despite the apparent sincerity and willingness or lack thereof of the people to offer the best so as to repair their standing with Yahweh, Yahweh's reply simply rejects the substance, desperation and the attitude it reflects with what seems a studied disdain. The proposals and assumptions are all false; Yahweh requires something much better than burnt

65 Jenson, Obadiah, Jonah, Micah, 171.

66 Hillers, Micah, 78; Tremper Longman III and David Garland, The Expositor's Bible Commentary, (Nashville, TN: Zondervan, 2008), 539. However, this proposal is not without precedent. Solomon who is reported to have sacrificed a thousand offerings

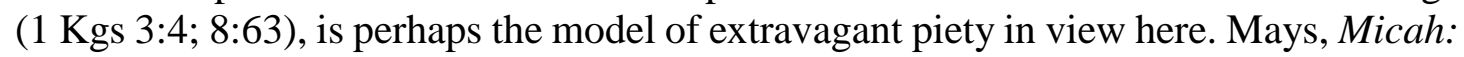
A Commentary, 140.

67 Although the practice of human sacrifice has been outlawed (Lev 18:21; Deut 18:10), it is particularly noted that such practice did take place in the time of King Ahaz, a notorious and certainly influential king during Micah's life and prophecy (Mic 1:1; cf. 2 Kgs 16:2-4). Dempster, Micah, 159.

68 Jenson, Obadiah, Jonah, Micah, 172.

69 Mays, Micah: A Commentary, 141. 


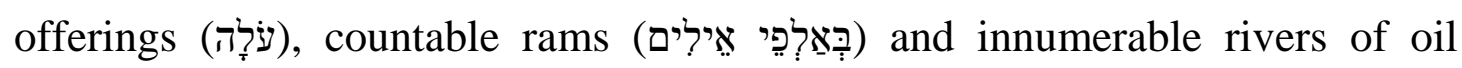

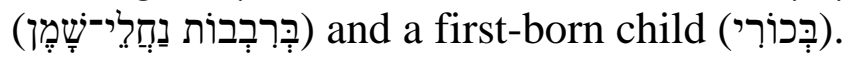

\title{
2. Social Obligations as markers of Ethical Religion (6:8)
}

6:8 He has told you, O man, what is good?

And what does the LORD require of you?

But to do justice,

to love kindness,

And to walk humbly with your God

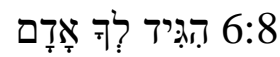

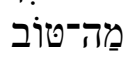

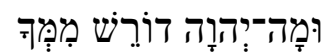

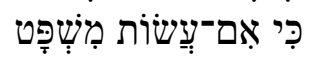

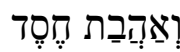

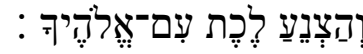

The indignant confrontation and misguided "what" (מָָה) of the people (6:6) is granted a calm, authoritative and composed response in the "what" (מָָה) of the prophet in the crowning verse (6:8), which has been rightly celebrated as the supreme definition of ethical religion and one of the great moral breakthroughs in history. ${ }^{70}$ Obviously, the petitioner's questions deal with "what" (מָה ) but the prophet's answers deal with how man should approach Yahweh. ${ }^{71}$ The concentration on the thing to be offered moved to a focus on the quality of life that is lived with whom one is joined by a social bond such as a covenant. In the answer, reproachful in its restraint, the petitioner is addressed with the surprisingly indefinite and inclusive vocative "man" (אָָָָָ) is a generic Hebrew term for humanity, and as Mays suggests it refers to "the generalizing and paradigmatic intention of the saying as a whole; its teaching is meant for any man in Israel."72 The "offering" that Yahweh truly desires is

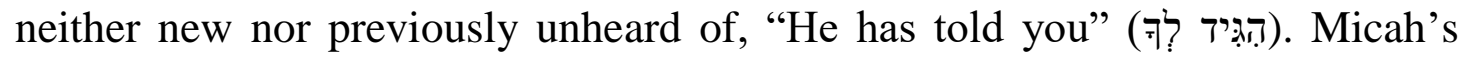
answer to what constitutes an ethical religion is conveyed by using the very fundamental understanding of Israel's faith. ${ }^{73}$ The declaration belongs to Israel's tradition and as such the petitioner needs only a reminder. It is however difficult to ascertain what setting the appeal to the past refers. According to Mays, "Probably the answer rest on a memory of what earlier prophets had said. The prophets spoke of YHWH's requirements under the theme of 'good' (Isa 1:17; 5:20; Amos 5:14f; Micah 3:1)."74

The meaning of the expression "what is good" (מַה־טובב) is determined within context and narrowly defined as what God requires of humanity. The "good" is what Yahweh requires; the right and true way to live, and this must have positive effect on people in community. In the Torah, what Yahweh desires is remarkably expressed and is similar to the requirement in Micah:

\footnotetext{
70 Andersen and Freedman, Micah, 504.

71 Hyman, "Questions and Response in Micah 6:6-8," 161.

72 Mays, Micah: A Commentary, 141.

73 Longman III and Garland, The Expositor's Bible Commentary, 540.

74 Mays, Micah: A Commentary, 141.
} 
And now, Israel, what does the LORD your God require from you, but to fear the LORD your God, to walk in all His ways and love Him, and to serve the LORD your God with all your heart and with all your soul, and to keep the LORD's commandments and His statutes which I am commanding you today for your good? (Deut 10:12-13, NASB).

There is a correspondence between what Yahweh is telling Israel and what he is doing; he distinguishes himself as someone who does justice and is interested in the plight of the week and oppressed (Deut 10:17-18). Thus the

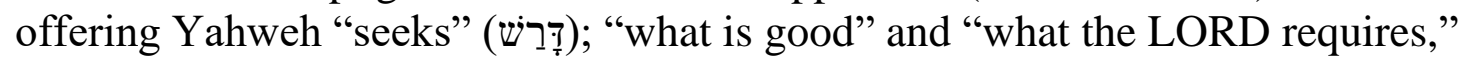
as a means of appearing before him when relationship has been fractured by transgressions, ${ }^{75}$ is found in three infinitival compact expressions that are related

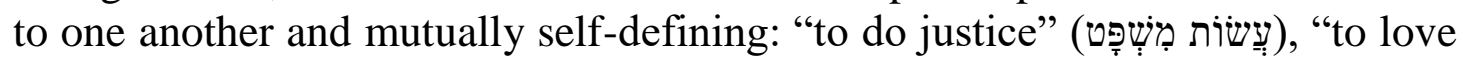

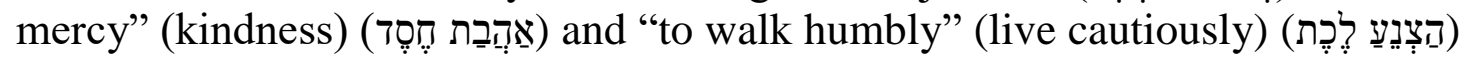

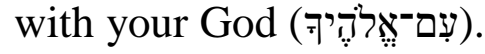

The first two requirements are fundamental to Israel's faith tradition. To do justice is "to uphold what is right according to the tradition of YHWH's will both in legal proceedings and in the conduct of life." 76 Proverbs 21:15 states, "The execution of justice is joy for the righteous, but is terror to the workers of iniquity" (NASB). The fundamental requirement to seek justice, though universally applicable, is given special emphasis by the covenantal character of Israel, who knew what it was to maintain the rights of the weak and oppressed (Deut 10:17-19; Ps 146:7). ${ }^{77}$ The combination of verb and noun; "love" and "kindness" (אַדְבַת חֶסֶד) is unique in the OT "since one usually does kindness."78 The Hebrew word הֶֶֶ is variously translated: "mercy" (NIV), "loyalty" (REB, NJB), "goodness" (NJPS). It usually implies help provided by a stronger person to a weaker member in a covenant relationship, the covenant relationship not always being necessary. ${ }^{79}$

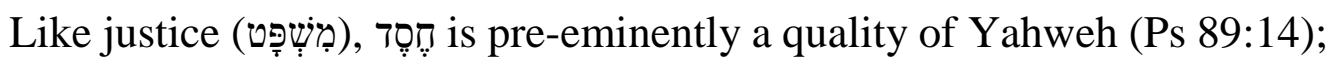
which must also characterize Israel's internal communal life (Hos 4:1; Mic 7:2). The practice of justice must rest on kindness and mutuality which recognizes the rights of the weak and oppressed and respond in brotherly identification. The combination of the requirement of justice and kindness does not imagine any form of divorce between the actions and the intentions; the inward and the outward expressions must correlate. The "love of kindness" (אָהְבַת דֶסֶד is interpreted by Brueggemann as "to practice a life of reliable solidarity." 80

75 Walter Brueggemann, "Walk humbly with your God: Micah 6:8," Journal for Preachers 33 (2010): 14-19 (14).

76 Mays, Micah: A Commentary, 141-142.

77 Jenson, Obadiah, Jonah, Micah, 173.

78 Dempster, Micah, 161.

79 Dempster, Micah, 161.

80 Brueggemann, "Walk humbly with your God: Micah 6:8," 14. 
Remarkably, the requirements of doing justice and loving kindness are quite clear in the HB/OT but the inclusive summary of the series, traditionally

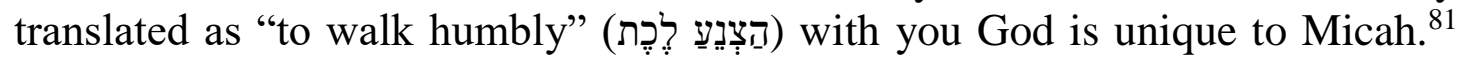
While walking (דָּרך) describes a quality of behaviour in relations to the fundamental metaphor of life as a journey, the verb הִצְנֵ way of life that is humble, not so much by modesty, as by considered attention to others. According to Hillers, "if correctly translated and explained here, the modifier would refer to employment of discretion, prudence, and wisdom in the religious life." 82 The humility implied here lies not in following one's own presumptuous ways, but in attending to the will and ways of Yahweh. ${ }^{83}$ A similar understanding is expressed by Stephen B. Dawes, "The worshipper is to be humble towards God (recognizing his dependence upon him and being willing to subject himself to him?), towards his fellows (being ready to put others first and give himself away in service to them?), and towards himself (shunning undue ambition, and cultivating a realistic sense of his own place and value?)." 84

The final phrase, "with your God," (עצם-אֶלהיף) resonates in the traditional covenant description associating Yahweh with "my people" $(6: 3,5)$ and such ideas as: "you shall be my people, and I will be your God" (Jer 30:22; cf. Ex 6:7; Hos 1:9). ${ }^{85}$ This idea of walking with God is a fundamental metaphor for Israel, and it contrasts later with walking in the statutes of the house of Omri (6:16). The good that Yahweh requires is the practice of justice, which is a way of loving kindness, and which consequently manifests in walking humbly with God. These are the essential pillars upon which Israel's covenant rests, but which in all of its aspects Israel has miserably been unsuccessful. While the answer does call for sacrifice, it is in fact a different sacrifice from that proposed by the question.

\section{E SYNTHESIS AND CONCLUSION}

Micah 6:6-8 presents two basic answers to the core question of how the individual should access Yahweh, especially when there is a dysfunction of relationship arising from violation of covenant requirements. The movement from where the people are to where Yahweh desires for them obviously requires a dramatic transformation of their perspective of ritual and socio-ethical consequences of their covenant relationship with Yahweh. Micah 6:6-8 thus presents a transformation of the situation, ${ }^{86}$ as the rhetorical "what" (מָז) develops most clearly into the calm climactic religious instruction of 6:8. The insightful movement from creation $(6: 1 b-2)$ to history $(6: 4-5)$ through cult $(6: 6-7)$ to

81 Hyman, "Questions and Response in Micah 6:6-8," 164.

82 Hillers, Micah, 79.

83 Mays, Micah: A Commentary, 142.

84 Stephen B. Dawes, "Walking Humbly: Micah 6:8 Revisited," Scottish Journal of Theology 41/3 (1988): 331-339 (338).

85 Jenson, Obadiah, Jonah, Micah, 174.

86 Marrs, "Micah and a Theological Critique of Worship," 199-200. 
ethics and theology $(6: 8)$ reaches comprehensively and collectively, all aspects of Israel's life. This characteristic creativity of the combination of different elements in a distinctive manner shows what the basic issue at the core of Israel's faith is. In the light of the historical connections reflected in the literary expression of the emotional and interpersonal aspects of the covenant in the drama of the unit, Micah highlights what Israel must know about Yahweh; "He does not want the gifts of people - no matter how extraordinary, how ornate, how sacrificial." 87

The social implications of the Israel/Judah's covenant failures are due to

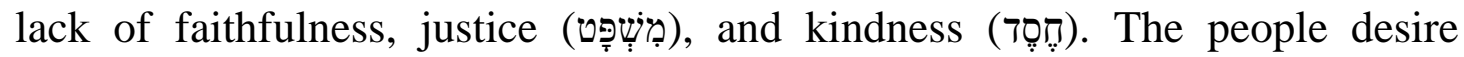
reconciliation and they begin realistically and leisurely with qualitative and quantitative proposals that rapidly become impossibly large. Their proposal indicates a bankruptcy and distortion in the moral and theological spheres, consequently the counterproposal of 6:8 is offered as a solution. Obviously, gifts and sacrifices could be means of making atonement for $\sin ($ Lev 4-5; 2 Sam 21:3; Ps 54:6), but Micah's critique indicates that these are altogether complete misunderstanding of the place and purpose of sacrifice in the divine-human relationship. If rituals and sacrifices are not congruent with a life of faithfulness with God; rituals without ethical behaviour permeating every aspect of life, are worthless. Something much more than mere ritual performance is required. What is most essential in the divine-human relationship; that which truly defines an ethical religion, as Micah 6:6-8 makes clear is not about increasingly extravagant and extreme extension of cultic practice but personal duty and responsibility for fulfilling that duty in society. The theological and catechetical significance of the sub-unit is captured by A.Vanlier Hunter:

The good that Yahweh seeks in every person among his people is rooted in making justice and steadfast love the controlling interests in all of life, thereby fostering a relationship with Yahweh that is characterized by paying careful and judicious attention to honoring his claim on all of life. This is the offering Yahweh accepts. ${ }^{88}$

Micah's message is not a rejection of ritual but maintaining the right priorities; it is the demonstration of the inseparable connection between ritual and social responsibility. Like ancient Israel/Judah contemporary faith communities may forget the ultimate sacrifice for God and consequently offer the wrong answers to questions regarding access to God within a context of true religion. They may be obsessed with extravagant and extreme performances of music, powerful sermons by distinguished charismatic and prophetic orators,

87 Dempster, Micah, 163.

88 A. Vanlier Hunter, Seek the Lord! A Study of the Meaning and Function of the Exhortations in Amos, Hosea, Isaiah, Micah, and Zephaniah (Baltimore: St. Mary's Seminary and University, 1982), 252. 
extravagant gifts of offerings and donations, super Sundays' commercials and the susceptibility of the evils of empty religion. They might seem to be dwelling in the sacred realm where the name of God is adored and are separated from the concern for social justice, the weak and helpless. On the contrary, Micah's idea of fellowship and walking with God defines such form of extravagant worship

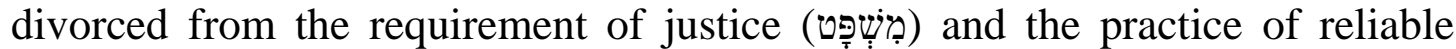
solidarity (אָהָבַת חֶסֶד), as meaningless. A truly ethical religion as Micah envisions, must exhibit moral coherence, remarkable and dependable solidarity with God and man conforming to social obligations. Most importantly, Micah 6:8 underscores the understanding that ritual and lifestyle go hand in hand, at least in the sight of God. The fundamental requirement of Yahweh is that a personal relationship with him must be manifested in a commitment to ethical living.

\section{BIBLIOGRAPHY}

Alfaro, Juan I. Micah: Justice and Loyalty. Grand Rapids: Eerdmans, 1996.

Allen, Leslie C. The Books of Joel, Obadiah, Jonah, and Micah, NICOT. Grand Rapids: Eerdmans, 1976.

Andersen, Francis I and Freedman, David N. Micah: A New Translation with Introduction and Commentary. Anchor Bible 24E. New York: Doubleday, 2000.

Barker, Kenneth L. "A Literary Analysis of the Book of Micah." Bibliotheca Sacra 155 (1998): 437-448.

Barton, John. "The Prophets and the Cult," Pages 111-122 in Temple and Worship in Biblical Israel. Proceedings of the Oxford Old Testament Seminar. Edited by John Day. New York: T\&T Clark, 2007.

Ben Zvi, Ehud Micah. Forms of the Old Testament Literature 21B; Grand Rapids: Eerdmans, 2000.

Berković, Danijel. "Aspects and Modalities of God's Presence in the Old Testament." KAIROS - Evangelical Journal of Theology III/1 (2009): 51-72.

Blenkinsopp, Joseph. A History of Prophecy in Israel. Louisville: Westminster John Knox Press, 1996.

Boloje, Blessing O. "Micah's Theory of the Justice of Judgement (Micah 3:1-12)." Journal for Semitics 26/2 (2017):689-710. https://doi.org/10.25159/1013-8471 12948.

Brueggemann, Walter. "Walk humbly with your God: Micah 6:8." Journal for Preachers 33 (2010): 14-19.

An introduction to the Old Testament: The Canon and Christian Imagination. Louisville, KY: Westminster John Knox, 2003.

Theology of the Old Testament: Testimony, Dispute, and Advocacy. Minneapolis: Fortress Press, 1997.

Carr, David M. An Introduction to the Old Testament: Sacred Texts and Imperial Contexts of the Hebrew Bible. Chichester: Blackwell Publishing, 2010.

Cuffey, Kenneth H. "The Coherence of Micah: A review of Proposals and a New Interpretation." DPhil. Dissertation, Drew University, 1987.

Dawes, Stephen B. "Walking Humbly: Micah 6:8 Revisited." Scottish Journal of Theology 41/3 (1988): 331-339. https://doi.org/10.1017/s003693060003146x. 
Dempster, Stephen G. Micah. The Two Horizons Old Testament Commentary. Grand Rapids, Michigan: William B. Eerdmans Publishing Company, 2017.

Gowan, Donald E. Theology of the Prophetic Books: The Death and Resurrection of Israel. Louisville: Westminster John Knox Press, 1998.

Hillers, Delbert R. Micah: A Commentary on the Book of the Prophet Micah. Philadelphia: Fortress Press, 1984. https://doi.org/10.2307/j.ctvb936jr.

Hrobon, Bohdan. Ethical dimension of the cult in the book of Isaiah. Beihefte zur Zeitschrift fur die Alttestamentliche Wissenschaft 418. De Gruyter: Berlin/New York, 2010. https://doi.org/10.1515/9783110247497.

Huffmon, Herbert B. "Covenant Lawsuit in the Prophets." Journal of Biblical Literature 78 (1959): 285-295. https://doi.org/10.2307/3264723.

Hunter, A. Vanlier. Seek the Lord! A Study of the Meaning and Function of the Exhortations in Amos, Hosea, Isaiah, Micah, and Zephaniah. Baltimore: St. Mary's Seminary and University, 1982.

Hyman, Ronald T. "Questions and Response in Micah 6:6-8." Jewish Bible Quarterly 33/3 (2005): 157-165.

Jenson, Philip P. Obadiah, Jonah, Micah: A Theological Commentary. Library of Hebrew Bible/Old Testament Studies 496. New York: T \&T Clark, 2008.

Kessler, John. Old Testament Theology: Divine call and Human Response. Waco, Texas: Baylor University Press, 2013.

King, Philip J. Amos, Hosea, Micah-An Archaeological Commentary. Philadelphia: The Westminster Press, 1988.

Lafferty, Theresa V. The Prophetic Critique of the Priority of the Cult: A Study of Amos 5:21-24 and Isaiah 1:10-17. Parkway: UMI Dissertation Publishing, 2010.

Laney, J. Carl "The Role of the Prophets in God's Case against Israel." Bibliotheca Sacra 138 (1981): 313-325.

Longman, Tremper III and Garland, David. The Expositor's Bible Commentary. Nashville, TN: Zondervan, 2008.

Malchow, Bruce V. "The Rural Prophet: Micah." Currents in Theology and Mission 7 (1980): 48-52.

Marrs, Rick R. "Micah and a Theological Critique of Worship." Pages184-203 in Worship and the Hebrew Bible: Essays in Honour of John T. Willis. Edited by M. P. Graham, R. R. Marrs \& S. L. McKenzie. JSOT Supplement Series 284. Sheffield: Sheffield Academic Press, 1999.

Mason, Rex. Micah, Nahum, and Obadiah. New York: T\&T Clark International, 2004.

Mays, James L. Micah: A Commentary. London: SCM Press Ltd., 1976.

McKane, William. Micah: Introduction and Commentary. Edinburgh: T. \& T. Clark, 1998

Mignon, Jacob. The Conceptual Coherence of the Book of Micah. JSOT Sup 322; Sheffield: Sheffield Academic Press, 2001.

Miller, Patrick D. They Cried to the Lord: The Form and Theology of Biblical Prayer. Minneapolis: Augsburg Press, 1994.

Mitchell, Eric A. "Micah - The Man and His Times." Southwestern Journal of Theology 46 (2003): 57-76.

Nogalski, James D. The Book of the Twelve: Micah-Malachi. Macon, Georgia: Smyth \& Helwys Publishing, 2011.

O’Brien, Julia M. Micah. Wisdom Commentary 37. Collegeville, Minnesota: Michael Glazier Book, 2015. 
Pawson, David. Unlocking the Bible: A Unique Overview of the Whole Bible. London: Collins, 2003.

Pierce, Timothy M. "Micah as a Case Study for Preaching and Teaching the Prophets." Southwestern Journal of Theology 46/1 (2003): 77-94.

Premnath, Devadasan N. "Amos and Hosea: Sociohistorical Background and Prophetic Critique." Word \& World 28/ 2 (2008): 125-132.

Provan, Iain, Long, V. Philips and Longman, Tremper III. A Biblical History of Israel. Louisville: Westminster John Knox Press, 2003.

Reimer, David J. "The Prophet Micah and Political Society" Pages 203-224 in Thus Speaks Ishtar of Arbela: Prophecy in Israel, Assyria, and Egypt in the NeoAssyrian Period. Edited by Robert P. Gordon and Hans M. Barstad. Winona Lake, Indiana: Eisenbrauns, 2013.

Simundson, Daniel J. Hosea, Joel, Amos, Obadiah, Jonah, Micah. Abington Old Testament Commentaries; Nashville: Abington Press, 2005.

Smith, Ralph L. Micah-Malachi: Word Biblical Commentary 32. Waco: Word Books, 1984.

Smith-Christopher, Daniel L. Micah: A Commentary. OTL; Louisville, Kentucky: Westminster John Knox Press, 2015.

Vaux, Roland de. Ancient Israel: Its Life and Institutions. Translated by John McHugh. The Biblical Resource Series 3. Grand Rapids, MI: Eerdmans, 1997.

Waltke, Bruce K. A Commentary on Micah. Grand Rapids: Eerdmans, 2007. . "Micah." Pages 591-764 in The Minor Prophets: An Exegetical and Expository Commentary. Edited by T. E. McComiskey. Grand Rapids Mich.: Baker, 1993.

Walton, John H. Matthews, Victor H. \& Chavalas, Mark W. The IVP Bible Background Commentary Old Testament. Downers Grove: Inter-Varsity Press, 2000.

Watson, Paul L. "Form Criticism and an Exegesis of Micah 6:1-8." Restoration Quarterly (1963): 61-72.

Wolff, Hans W. Micah: A Commentary. Translated by Gary Stansell. Minneapolis: Augsburg Fortress, 1990.

Blessing Onoriode Boloje is a lecturer at the Baptist Theological Seminary, EkuNigeria; Research Fellow of the Alexander von Humboldt Foundation, RuhrUniversität Bochum, Germany; and Research Associate, Department of Old Testament Studies, Faculty of Theology, University of Pretoria, South Africa. Email: pstbobson@yahoo.co.uk ORCID: https://orcid.org/0000-0002-74803805 . 